\title{
剝離タイルの振動特性と触診型検知方法に関する研究 \\ 模擬剝離タイルを用いた検討 \\ VIBRATION CHARACTERISTICS OF TILE IN PEELING OFF AND A NEW TOUCHING DIAGNOSTIC METHOD
}

岩瀬 昭 雄*

Teruo IWASE

\begin{abstract}
Tile is water-proof, beautiful and useful materials, but it has fatal problem that it may be peeling off. So, skillful workers often have to make hammering tests for all tiles.

From experimental study, it could be found that such a tile was vibratory in frequency range from $1 \mathrm{kHz}$ to $2 \mathrm{kHz}$. Based on the result, author proposed a new detecting method that is feedback circuit using twin piezo-electric buzzers, for touching to a tile, and as for input and output. It could oscillate and radiate a sound only when touched to a tile in peeling off.
\end{abstract}

Keywords : tile, peeling off, diagnostic technique, feed back loop circuit, piezo-electric, oscillation タイル, 㓦離, 診断技術, 帰還回路, 圧電素子, 発振

\section{1.はじめに}

タイルは酎水性や耐候性と美麗さを兼備えた材料とし て水掛かり部分の内装や外壁や床の仕上げに欠かせない 建築材料であり ${ }^{1)}$, 昨今の建物の高級化傾向に伴い，外 壁にタイルを使用する例が非常に多く見受けられる。こ れは街の美観向上にも役立つもので大変喜ばしいことで あるが，タイルには不注意な施工により時間の経過に 伴って剶離を生じる問題があり，気付かず放っておくと 外壁タイルが路上へ落下する事故の危険性もあり，上記 の建築状況にかんがみて, 剥離を検知して事故の事前防 止をはかる技術や管理体制の確立が今後ますます重要と なると思われる。

壁面タイルの管理方法については, タイル職人が一枚 ずつハンマーでタイルをたたき，剥離タイルと正常に接 着されている夕イルとの音色を聞き分ける方法が従来か ら有名であるが，建物の高層化が進む昨今では高所で危 険を伴う作業になることも多く，打撃と音色の判断を職 人に代り行う外装監視ロボットが開発されている2)。

また，剥離タイル裏面に薄い空気層が形成され熱抵抗 が増加する。壁面構成が単純で建物内外に温度差がある 場合, 正常な部分と㔀離部分のタイル表面温度が微妙に 異なることに着目した非接触検知法も開発されている。 このような検知方法が，タイル職人による原始的な方
法に代って普及することが望まれる一方，例えば打撃口 ボット式では複雑になりがちな打撃機構を必要とし, 表 面温度測定方式では, 高価な計測装置が必須, かつ建物 内外の温度等気候条件の影響を受けやすいことなど, 新 しい手法それぞれに問題が残され，特定のどれかが優れ た方法として確立されていないばかりか，簡便さのみで 言えばタイル職人の打撃法が今なお遙かに優位と言え る。

そこで，著者は，打撃による剝離タイルの検知法の根 拠である音色の違いの原因である剥離タイルと非剝離夕 イルの振動特性そのものの相違を模擬剝離タイルによる 実験で調べた。さらに，明らかとなった振動特性の大き な差異に着目した検知法の一例之して, 触診型の検知方 法を提示した ${ }^{3), 4 \text { 。 }}$

実験結果に基ついた検知原理は単純明快で, 㔀離か非 剥離は未熟練者で分かるような発音の有無で示される。

しかも「タイル職人の打撃と音色の判断作業」を再現 するロボットやエキスパートシステムとは異なって具体 的な検知装置に打撃機構は不要であり，タイル職人が持 つハンマー一本には及ばないとしても，それと大きく変 わらず極めて安価に実現可能な点は, 前述の新しい2 の検知方法と比べても大変優位なことと言える。外装夕 イルの施工例の多くが管理点検すべき時期を迎える今後 
を考えれば，実験で明らかになった剝離・非剝離夕イル の振動特性の相違の周知亡このような検知装置の例示は 社会的に有用なことと考えられる。

よって本論文では，模擬剝離タイルの振動特性に関す る実験結果と触診型の剥離タイル検知方法の原理および その試験例について詳しく述べることとする。

\section{2. 剝離タイルの打撃音の解析実験}

剥離タイルの検知法を考えるには，剝離タイルと正常 なタイルとの物理的な特性の違いを知る必要がある。

そこで，従来からタイル職人が行ってきた打撃音によ る剝離タイルの検知法の根拠を簡単な実験で調べた。

対象は当大学のある室内で, 壁面端部にタイルの脱落 が散見される程度の袔離状態から正常な接着状態までが 混在する壁面で, 㓦離, 非剝離のタイルの音色の違いが 明瞭に判別できる部分ごとに打撃し実験を行った。

まず試しに，小型の鉄製のハンマーで剝離タイルと正 常なタイル $\left(98 \times 98 \times 4 \mathrm{~mm}^{3}\right)$ の両者を打撃し, それぞ れの打撃音に音色の違いがあることに着目してFFTに よる周波数スペクトルを観測した。

その結果, 打撃音のスペクトルの違いは明白で, 正常 なタイルの場合ではあまり特徴の無い平坦なスペクトル 性状であった。これに対して, 㔀離タイルの場合のスペ クトルでは中高音域で相対的にレベルが高くなる部分が 観測され，これによって音色が特徴づけられるのを聞き 分け，剥離状態を検知していると推測された。

さらに，打撃音は夕イル面の振動に伴って放射される もので, 同種のタイルが正常と剥離状態とで振動特性が 大きく異なる結果が認知されると考え, 前述の壁面で, タイル表面を加振した時の正常接着タイルと虽離タイル 両者の振動特性の相違を調べる実験を引続き行った。

その測定系統を Fig. 1 に示すが, 約 $5 \mathrm{~g}$ の糸吊り小鉄 球をタイル壁面から斜上方向に電磁石で吸い付け, 電流 を断って落差 $2 \mathrm{~cm}$ に応じた速度で衝突打撃させた。
剥離, 非剥離タイルの両表面には重さ $1.8 \mathrm{~g}$ の小型加 速度ピックアップを薄い両面テープで接着させ, 打撃加 振による夕イルの加速度応答と放射音の録音を行った。

分析は最も単純に, この録音をFFT 分析器によりス ペクトル解析した。Fig. 2 に振動加速度応答と放射音の 正常なタイルと剥離タイルとの場合を比較して示す。

これを見ると，正常に接着されたタイルの場合，振動 加速度応答は低音域から高音域まで平坦で, 際立った特 徵は胃いだしにくい。放射音についても数 $\mathrm{dB}$ の凹凸は 認められるもの，ほぼ平坦な周波数特性となっている。

一方, 剝離夕イルの場合, $2 \mathrm{kHz}$ 以上で $10 \sim 20 \mathrm{~dB}$ 程 度, 加速度応答のレベルが幅広くかつ高い部分が認めら れる。このように, 㓦離状態となるとタイル表面が大変 励振されやすい特性に変化すると推測される。

放射音の場合，加速度応答で最もレベルが高い $2 \mathrm{kHz}$ の周波数を中心にブロードなピークが認められ，タイル 表面の音響放射能率の影響を受けつつも，基本的には剥 離状態のタイルの振動特性で特徴付けられることが分か る。

\section{3. 剝離タイルの振動特性に関する実験}

以上に述へた予備実験から放射音にタイル自身の振動 特性が大きく関与することが判明したので，タイル面の 振動特性自体が剝離状態と非剝離状態でどのように異な るか，実験により検討することとした。

\section{1 タイルの振動特性に関する予備実験}

この実験では，同種のタイルで剥離状態と非剝離状態 の接着状態を実験する必要があり，実際の施工と同様に モルタルでコンクリート軀体に接着させ，正常接着され た状態と剝離状態とを同時に夷現するのが理想的であ る。

しかし,試験体作製でモルタル硬化に長い時間を要し， その長い硬化時間後に剝離, 非剝離状態を想定よ゙おり安 定して得にくいことが判明したので, 石こうとモルタル
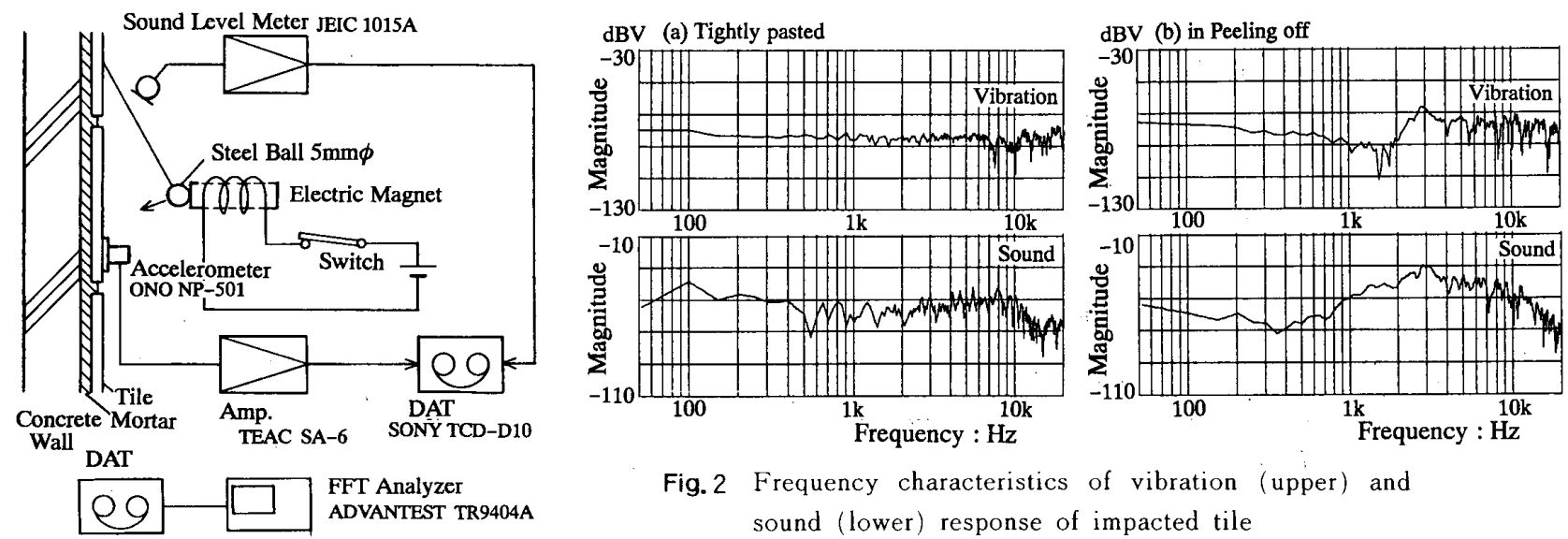

Fig. 2 Frequency characteristics of vibration (upper) and sound (lower) response of impacted tile

Fig. 1 Measuring and analyzing set-up for response of impacted tile 
Table 1 Sizes of tiles used in experiment

\begin{tabular}{|cr|r|}
\hline \multicolumn{2}{|c|}{ Square } & \multicolumn{1}{c|}{ Rectangle } \\
\hline \multicolumn{2}{|c|}{ (1) $149 \times 149 \times 9.0$} & (7) $226 \times 60 \times 9.5$ \\
(2) & $92 \times 92 \times 8.0$ & $(8) 198 \times 98 \times 7.0$ \\
(3) & $75 \times 75 \times 5.0$ & (9) $190 \times 45 \times 7.8$ \\
(4) & $44 \times 44 \times 6.3$ & (1) $107 \times 59 \times 7.5$ \\
(5) & $25 \times 25 \times 4.6$ & (1) $95 \times 45 \times 7.5$ \\
(6) & $18 \times 18 \times 5.0$ & $($ unit $\mathrm{mm})$ \\
\hline
\end{tabular}

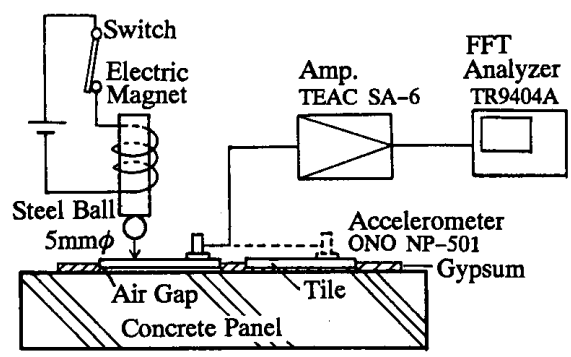

Fig. 3 Measuring set-up for comparisons of vibration characteristics between test pair tiles tightly pasted and peeling off

の接着が同等であれば, 剝離タイルと力学的に非接触部 の接着剤がモルタルと石こうとでは大きな差を生じない と考え，コンクリート試験体の整形に利用され硬化時間 も短い石こうを接着に用いる方針とし，その妥当性をま ず検討した。

試験体は厚さ約 $65 \mathrm{~mm}$ のコンクリートパネルに接着 して作製した。石こうによる場合，同種タイル二枚の一 枚のみ裏面（接着面）に石けん液を塗布してから接着す ることで剥離状態が安定に実現でき，正常に接着した非 㔀離状態のタイルとが並んだ試験体を得た。一方，モル タルの場合, 吸水養生の省略などを試み, 硬化後, さら にその後と, 打撃音の違いからいく体かの剥離状態が確 認できた。

実験の測定分析系統を Fig. 3 に示すが，試験体の約 $10 \mathrm{~mm}$ 程度上から直径 $5 \mathrm{~mm}$ の小鉄球を自由落下させ, 重量 $1.8 \mathrm{~g}$ の小型加速度ピックアップの出力を FFT 分 析器に導き, 衝撃応答を求めて剝離の有無とタイル面の 振動特性の関係について比較検討した。なお，加速度応 答は相対レベルで表示した（-20 dBV が $1 \mathrm{G}$ に相当）。

予備実験の結果として, Fig. 4 にサイズ $75 \times 75 \times 5$ $\mathrm{mm}^{3}$ の夕イルの場合をそれぞれの条件ごとの加速度応 答を, 測定機器のノイズを含めた暗振動の分析結果と合 わせ示す。

まず,Fig.4(b)，(c) の非剥離夕イルの結果を見ると， モルタルと石こうのいずれでも $5.5 \mathrm{kHz}$ 付近をはじめ として高音域で鋭くQの高いピークが暗振動レベルか ら数個浮き出しているのが認められる。Fig. 4(d)，(e) の剝離状態での結果では, 低域でおおむね平坦で, 高域 では 4 5 kHz や7 9 kHz に比較的ブロードで優勢な

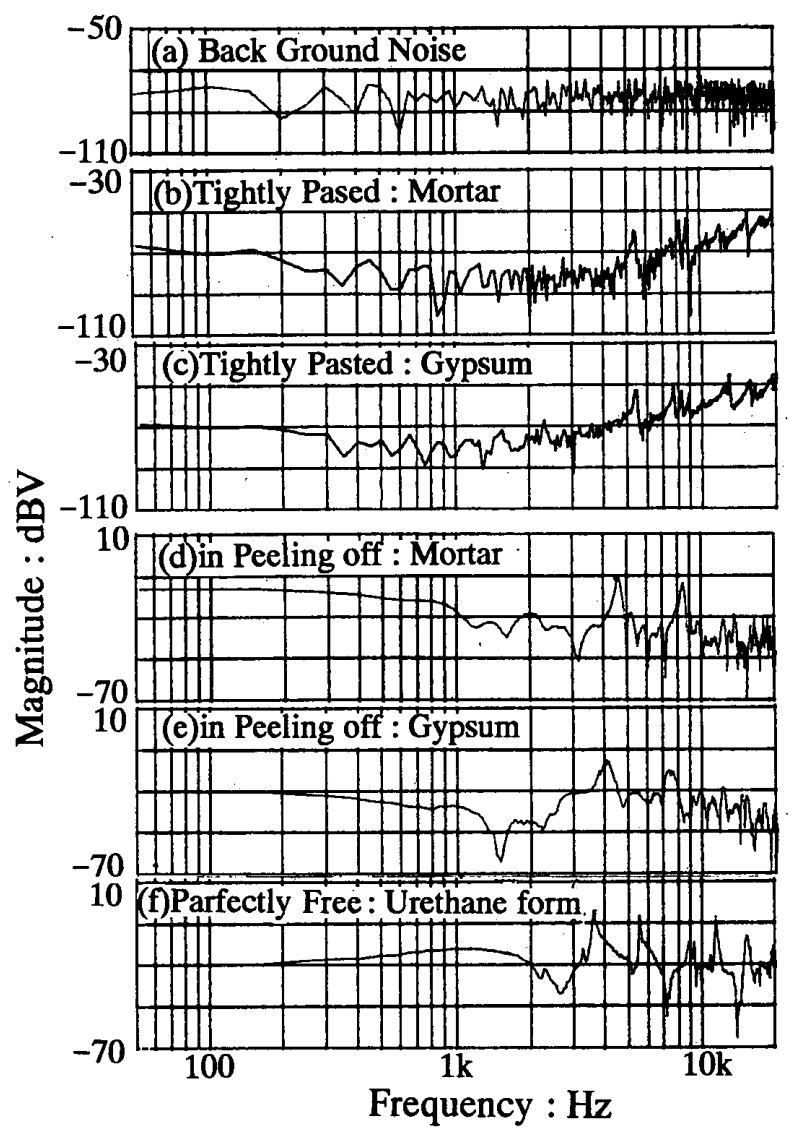

Fig. 4 Comparisons frequency characteristics of vibration responses of impacted tiles

ピークが認められるほか, 加速度応答のレベルが全般的 に高いことが分かる。主要なピーク值を比較すると非剥 離状態の正常のものより $20 〜 30 \mathrm{~dB}$ は高いことなどが 分加る。

また, 非剝離状態の石こう接着ではモルタル接着より いく分応答が大きい傾向が認められる。さらに, 剥離状 態での加速度応答のピーク周波数に多少の相違がある が，比較的類似の応答が得られ，石こう接着によっても， モルタル接着とほぼ同様に剝離・非剥離の振動特性の大 きな差異が把握可能なことが分かった。

参考までに上述の実験対象のタイルをウレタンフォ一 ム上に単純に置き加振した加速度応答を Fig. 4(f) に 示すが，これには， $3.5 \mathrm{k}, 5.5 \mathrm{kHz}$ 等夕イル自体の固有 振動と思われる鋭くレベルの高いピークが数個認められ る。

一方，タイルが剥離状態にあるときは，目地部や裏面 の不完全な接着による拘束が加わり，これら鋭い固有振 動の周波数がずれたり, 鋭さが抑制され, Fig.4(d), (e) に示す特性となると考えれらる。しかし，その拘束は， 裏面すべて接着拘束されて母材とほぼ一体運動する非剝 離状態よりはるかに緩やかで, タイル単体で実効質量も 軽い比較的自由な振動状態亡推測される。

3.2 模擬剝離タイルによる実験結果

上に述べた実験の考察に基づき，早く硬化して迅速に 
試験体が得られる石こうを用い て剥離タイルの振動特性に関す る実験を行っても結論に大きな 誤りは生じないと判断し，タイ ルの種類を広げて実験を継続す ることとした。

試験体の種類としては通常の 建築施工で広く用いられている ものの代表として Table.1に 示すような形状，サイズおよび 厚さの異なるタイル 11 種類を 選定した。

これらの試験体を用いて基礎 実験と同様の方法で衝擊加振に 対する加速度応答を調べた。こ 'の実験の場合, 一部の試験体の 応答か強くて測定系の飽和の危 険性があり，小鉄球の落下高は 予備測定より低めて約 $5 \mathrm{~mm}$ と

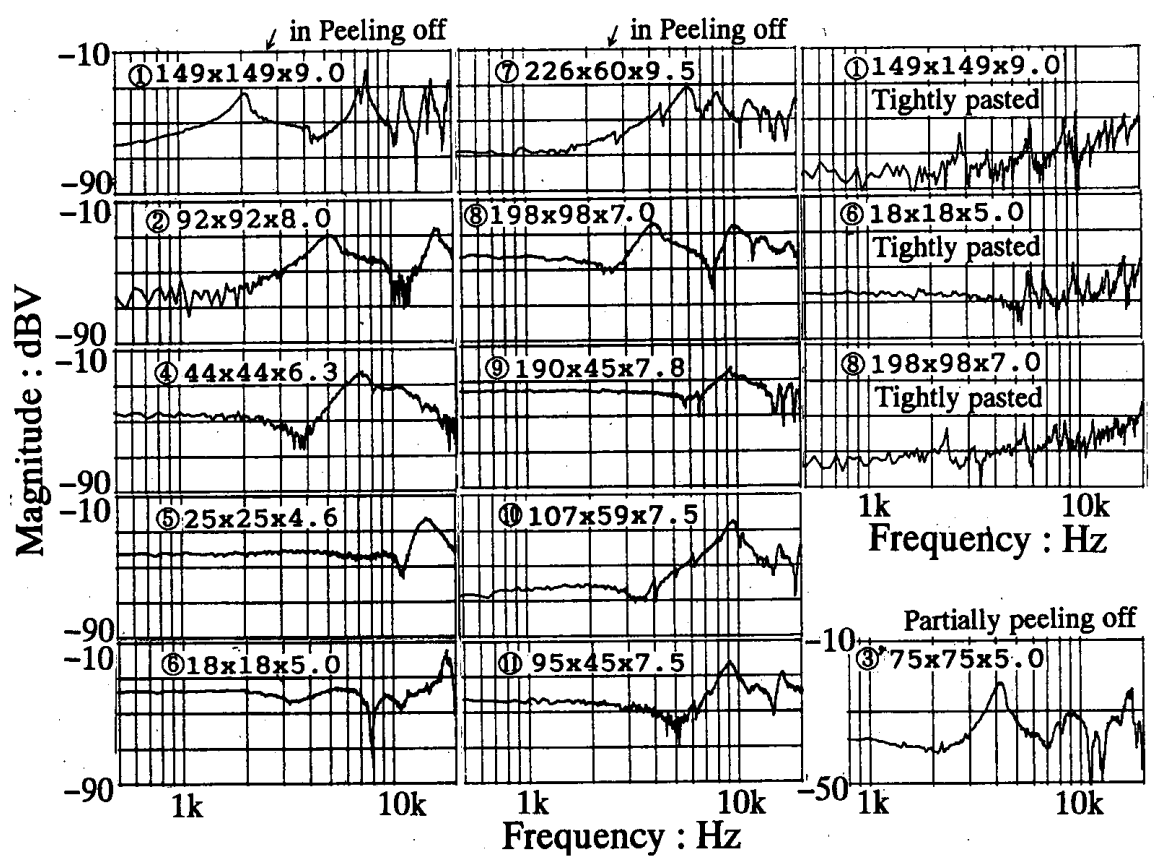

Fig. 5 Comparisons frequency characteristics of vibration responses of impacted tiles varying side size and thick

した。

実験結果として, 剥離夕イルは 10 種類, 非剥離夕イ ルは試験体ごとに 3.1 に述べた以上の特徴は見出しにく いが，参考までにサイズの面から 3 種類を代表に選び， それぞれの加速度応答を Fig. 5 に示す。また， $75 \times 75$ $\times 5 \mathrm{~mm}^{3}$ のタイルに関してはすでに Fig. 4 に示してい るので，同サイズで部分剝離タイルの剥離部分を衝撃加 振した場合の応答の例（3.4にて後述）を示した。

㓦離タイルの結果を見ると，まず正方形タイルで試験 体中最大サイズの(1)の加速度応答には $2 \mathrm{k}, 8 \mathrm{k}, 12 \mathrm{kHz}$ 等, 最も小さな66では $18 \mathrm{kHz}$ のみと，タイルの形状や サイズによって様々であるが， $1 \mathrm{kHz}$ 以上の領域にブ ロードなピークが必ず観測されることが分かる。その ピークレベル值は最も低い周波数のものが最大になる ケースが多い。正方形タイルでは，サイズが小さくなる に従いピークの周波数がより高い方へ移行し, かつピー クレベルが高くなる様子が大まかな傾向として認められ る。しかし，長方形タイルのピーク周波数の高低と長辺 サイズとの関連は読み取り難いことも分かる。

さらに，ピークの裙野や平坦な部分の周波数において もFig.4(a) に示した暗振動レベルょり高い値を示し, 特定の周波数以外にも全般的に振動しゃすい状態にあ る。

これを言いかえれば, 前述のとおり非剝離状態では母 材に接着され一体運動して実効質量が大きいのに対し， 剶離状態となると, 母材から独立した夕イル単体の実効 質量ははるかに軽くなり, タイル表面の機械インピーダ ンスが低下する。さらに，タイル自体の固有振動や共鳴 現象により，周辺の支持条件などで定まる特定の周波数

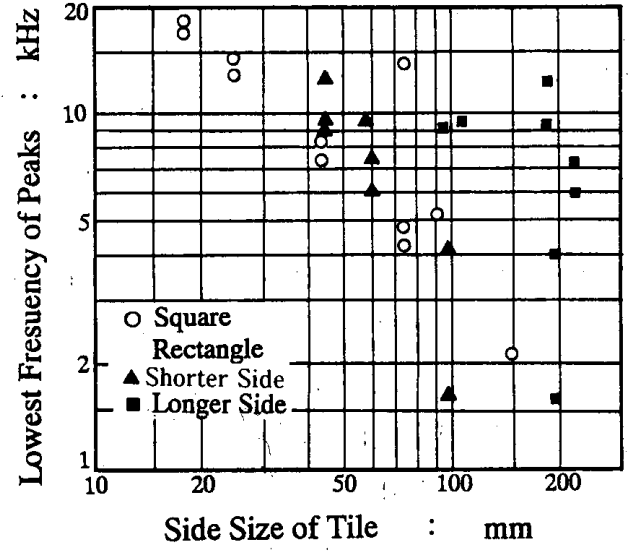

Fig. 6 Relations between observed lowest frequency of peaks in response of impacted tile and side size

で機械インピーダンスの顕著な低下が加わると推察され る。

\section{3 單離タイルの振動特性と寸法に関する検討}

模擬剝離タイルの衝撃加振に対する加速度応答の観測 結果から加速度応答, すなわち剥離夕イルの振動特性亡 タイルの寸法に大まかな関連が見受けられた。

そこで，まずピーク周波数に関し検討した。

Fig. 6 は，それぞれの試験体ごとの最も低域側のピー ク周波数を代表としてタイルサイズとの関係で整理した もので，長方形タイルの場合; 長辺サイズよりも短辺サ イズとの関連の方が強いことが伺える。

次いで，模擬㓦離タイルの試験体では裏面全体が剥離 状態にあり，目地部のみで石こうで接着した緩やかな拘 束と考え，各サイズごとに（1）に示す単純支持条件の 板振動理論 ${ }^{5)}$ による $(1,1)$ モード固有振動数と観測さ 


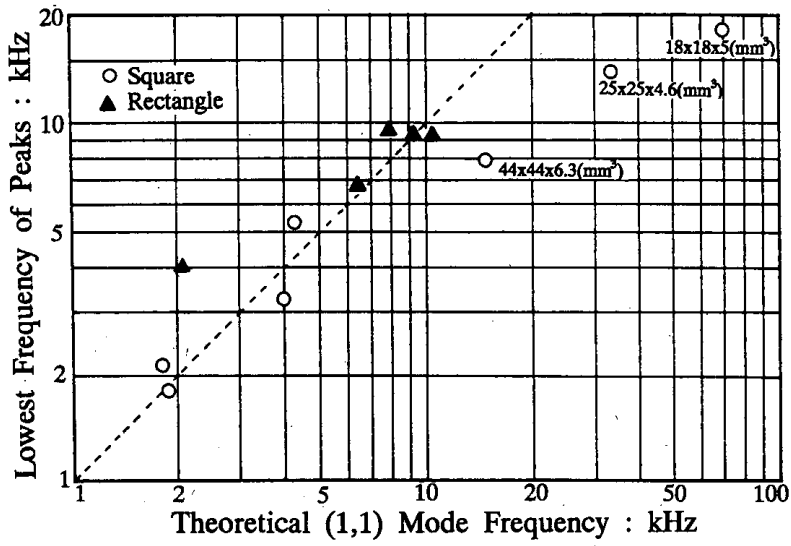

Fig. 7 Relations between observed lowest frequency of peaks in response of impacted tile and theoretical $(1,1)$ mode frequency

れた優勢で最も低いピーク周波数との対応関係を調べ た。

$$
f_{r}=(\pi / 2) \sqrt{B / m}\left(p^{2} / a^{2}+q^{2} / b^{2}\right)
$$

ただし， $m$ は板の面密度， $B$ は曲げ剛性 $\left(E t^{3} / 12\right)$, $p, q$ は自然数, $a, b$ は板の寸法, $E$ はヤング係数, $t$ は板厚。タイルの物性値には幅があるが, 某メ一カーの 内部資料を参考に, 縦波速度 $C l=\sqrt{E / \rho}=5000 \mathrm{~m} / \mathrm{s}$ 之 最も単純な形で与え計算した。

その結果を Fig. 7 に示すが，寸法の大きなタイルは ほぼ対応し，理論値が超音波領域に含まれるような小さ なタイルでは，実際に観測されるピーク周波数はこれよ りかなり低いことが分かる。後者の場合, 縦横寸法と厚 みが近く,板振動理論が適用できないためと考えられる。

なお, 固定支持条件の $(1,1)$ モードの近似解 ${ }^{6}$ では, ( 1 ) 式の $1.8 \sim 2.2$ 倍之高くなる。今回の実験結果に限つ ては対応が悪いが, 実際の多様な剝離状態のピーク周波 数の推定では念頭に入れておく必要があろう。

さらに, 背後密閉空気層が形成され, スチフネスが夕 イルの㴊性と比べて無視できない場合の固有振動数 $f_{r a}$ は膜振動の固有振動数を $f_{s}$ として以下で与えられる7”。

$$
\begin{aligned}
& f_{s}=\sqrt{\rho_{0} c^{2} / m L} / 2 \pi \\
& f_{r a}=\sqrt{f_{r}^{2}+f_{s}^{2}} \ldots \ldots \ldots
\end{aligned}
$$

ただし， $\rho_{0}, c, L$ は空気の密度と音速，空気層厚

ここで $t=5 \sim 10 \mathrm{~mm}, L=0.1 \mathrm{~mm}$ とすると (2).式 の寄与は $1.3 \sim 1.7 \mathrm{kHz}$ であり, 実際に密閉空気層が形 成されるかは別として，(1) 式で $2 \mathrm{kHz}$ と計算される 例では $2.6 \mathrm{kHz}$ にシフトする程度の影響が計算上見込 まれる。

以上の実験結果やピーク周波数とタイルサイズに関す る考察から，実験対象とした程度のサイズを有する剥離 タイルの場合には $1 \mathrm{kHz}$ 以上の周波数領域に固有振動 数, すなわち励振されやすい周波数が存在すると考えら れる。いくぶん大きめのタイルでも 2 次以上のモードを 含めれば同様の結論が導かれることになろう。

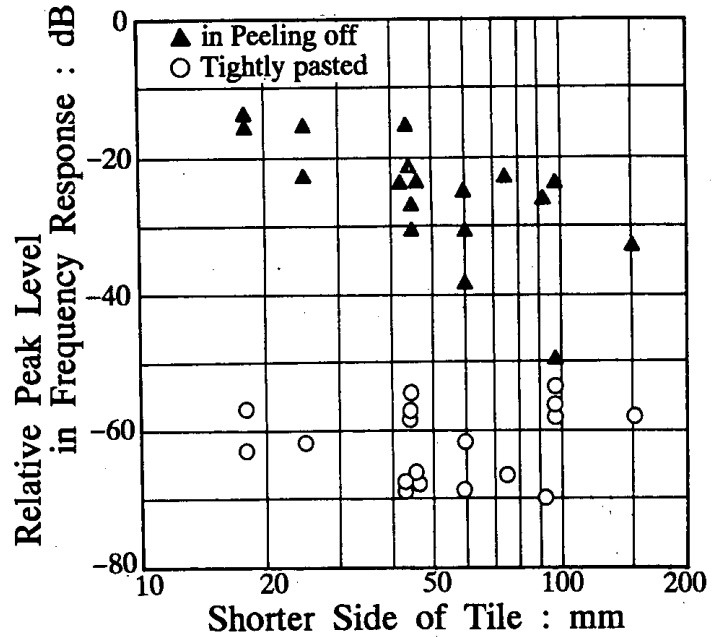

Fig. 8 Relations between maximum peak levels in frequency response of impacted tiles and their shorter size

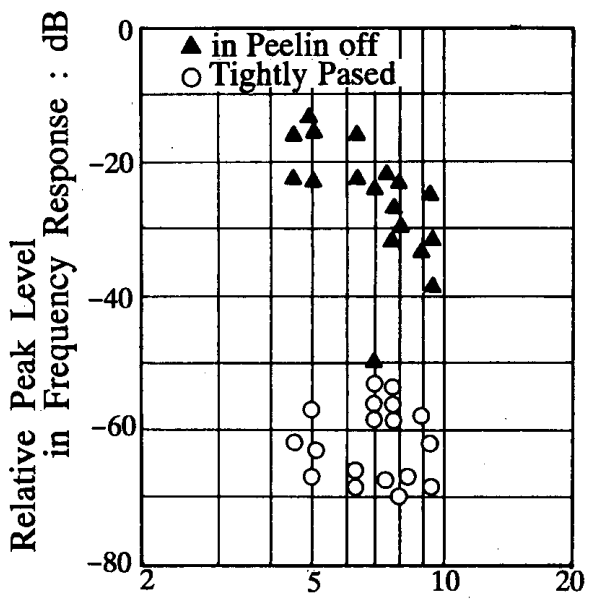

Thickness of Tile : mm

Fig. 9 Relations between maximum peak levels in frequency response of impacted tiles and their thickness

理論值への適合はともあれ, 実際に現れる固有振動数, すなわち振動しやすい周波数に関し，まとまりある特徵 は検知方法を考えるうえで大変有利な条件となる。

次いで，打撃加振に対する分析結果加ら剝離・非剝離 状態の励振されやすさの差を数值的に検討した。

前述のように正常なタイルの加速度応答では，ピーク 自体は鋭いが全般的にレベルは低い。一方，剥離タイル ではピークの鋭さは失われてなだらかであるが，ピーク のレベル自体は高い。この両者の比較のため, 最も単純 に剥離タイルのブロードなピークレベルと正常なタイル の鋭いピークのレベルの最大のものを試験体ごとに求め た。その結果として試験体のタイルの短辺とピーク值の 関係をFig. 8, タイルの厚さとの関係を Fig. 9 に示す。

前者を見ると，同じ種類（短辺寸法）のタイルでは， 㓦離, 非剝離で $20 \sim 30 \mathrm{~dB}$ の差が認められる。後者か らは一部を除き，タイル厚さが $4.6 \sim 9.5 \mathrm{~mm}$ の範囲内 で, 剝離夕イルの加速度応答振幅は厚みの 2 3 乗に反 比例するような傾向とともに㔀離タイルが正常なタイル 


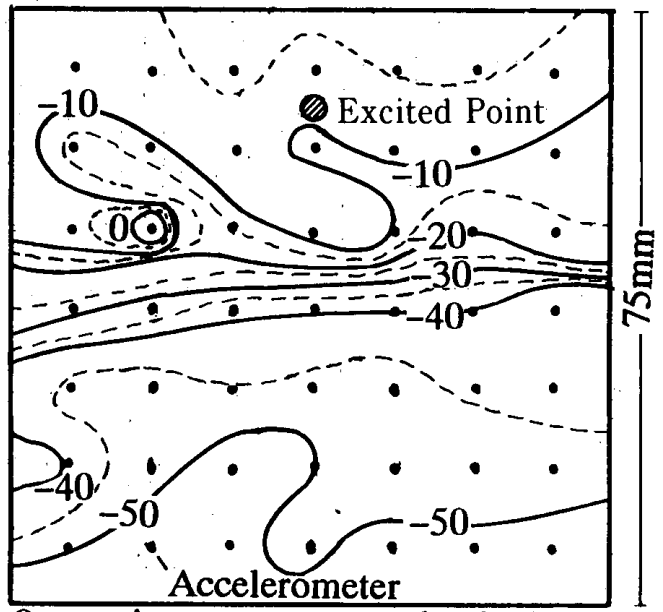

$0:$ maximum response value in $\mathrm{dB}$

Fig. 10 Contour line of averaged responses in 3 -frequencies $(1 \mathrm{~K}, 2 \mathrm{~K}$ and $3 \mathrm{kHz})$ on a tile partially (upper half) peeling off

に比べかなり励振されやすいことも明瞭である。

3.4 部分剶離タイルの振動特性

前述の模擬剥離夕イルの実験はタイル裏面全体が剥離 して目地部のみで接着している脱落直前の状態を想定し たものであり，脱落事故には直結しないが，全面剶離に 至る段階を想定した部分剥離に関する実験も加え行っ た。

実験対象としては $75 \times 75 \times 5 \mathrm{~mm}^{3}$ のタイル裏面の上 半分に石けん夜を塗布してコンクリートパネルに石こう で接着したものを用い，㓦離部分に小鉄球を落下させ， タイル面上 49 点でその時の加速度応答を求めた。

受振位置が剥離部分にある場合, 受振位置ごとにピー ク周波数やピークの数が異なる応答が観測されるが, Fig. 5(3) を代表として, 剝離タイルの一般的な特性が, また非剥離部分の受振位置では非剝離状態の一般的な弱 い加速度応答が得られた。さらに，ピーク值を避けて加 速度応答の $1,2,3 \mathrm{kHz}$ の 3 周波数における平均值から 見た全般的な励振特性の夕イル面上での分布状態を Fig. 10 に示すが, 剝離部分と非剝離部分が明瞭に区分 されている。この他，同試験体で非剝離部分を打撃した 実験や $1 / 4$ 䟝離タイルを用いた同様の実験も行った結 果, 剥離部分を加振して剥離部分で受振した場合のみ剝 離状態の一般的な加速度応答が得られることが判明し た。

すなわち, 部分剝離夕イルの振動特性は, 大まかに言 えば剥離部分はそのまま剥離タイルと同等の，また非剝 離部分は非剝離状態として観測できることが分かった。

\section{4. 剥離タイルの触診型検知方法}

剝離状態のタイルは, $1 \mathrm{kHz}$ 以上の周波数範囲で励振 されやすいとの結論に基づき，打撃のような複雑なメ力 ニズムが不要で, 操作も簡単な以下の検知回路を考えた。
1）増幅器の入出力部にタイルの表面に接触させた振動 電気変換素子を対で接続し，タイルの励振特性を回路ゲ イン（増偪度）に反映させた帰還回路を構成。

2）この回路ゲインをある值に設定すると，正常な非剝 離タイルに接触した時には励振されにくく,タイルを経 由して入力部に戻る電圧は不十分で何も生じない。

3）励振されやすい剥離タイルに接触した時には，回路 の出力がタイルを経由して大きく入力部に戻るので, ループゲインは十分高くなり，正为還条件でゲインの最 も大きくなる周波数で発振が開始，持続される。

4）無接触状態では閉ループが形成されず発振しない。

\section{1 圧電ブザーの加振・受振特性}

具体的な剝離夕イルの検知回路に用いる振動電気変換 （入出力）素子として, 振動加速度ピックアップと動電型 加振器がオーソドックスであるが, 価格やサイズ等に問 題がある。剝離タイルの振動特性に着目して別の素子を 選定すれば，振動しやすい帯域に感度を有し，駆動電力 もわずかな圧電スピーカーや圧電ブザーが有力となる。

原理どおりに加振と受振 (入出力) の両面でこの圧電 素子が流用できれば極めて安価で好都合と考えられるの で, その利用の可能性について以下の実験を行った。

すなわち, サイズ $75 \times 75 \times 5 \mathrm{~mm}^{3}$ の剥離タイルの試 験体に直径 $27 \mathrm{~mm}$ の圧電ブザーを二枚薄い両面テープ で対に張り付け，片方にホワイトノイズを印加してタイ ル面に励起される振動加速度と励起された振動から他の 圧電ブザーに生じる電圧を分析して総合的な変換特性を 調ベた。

これらの実験結果をFig.11に示すが，Fig.11(a)に 示した剝離タイル面の振動では $3 \mathrm{kHz}$ 以上の周波数領 域にレベルの高い部分が観測され，压電ブザーで剝離夕 イルの加振は可能であることが分かる。さらに圧電ブ ザーで受振した結果をFig. 11（b) に示すが, 剥離夕イ ルの励振されやすさが圧電ブザーの変換周波数特性を通 して緩やかなピークとして反映されることも分かった。

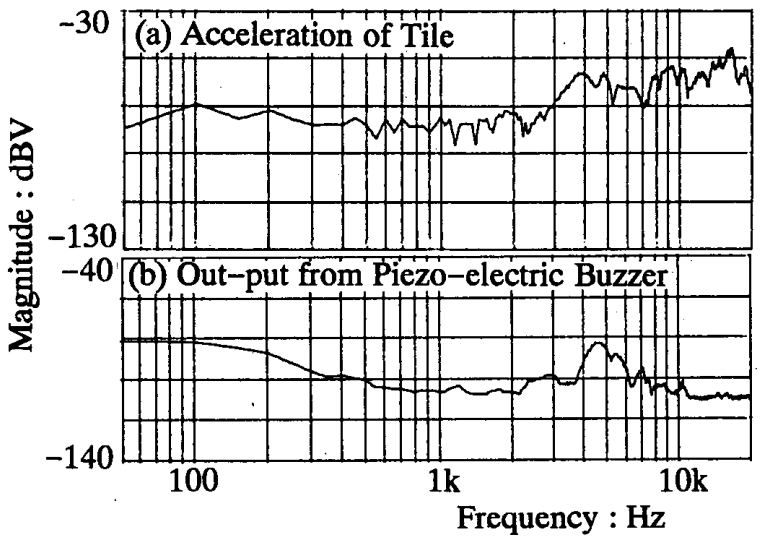

Fig. 11 Acceleration of tile excited by white nosie via piezoelectric buzzer and output signal from another piezoelectric buzzer pasted on the same tile 


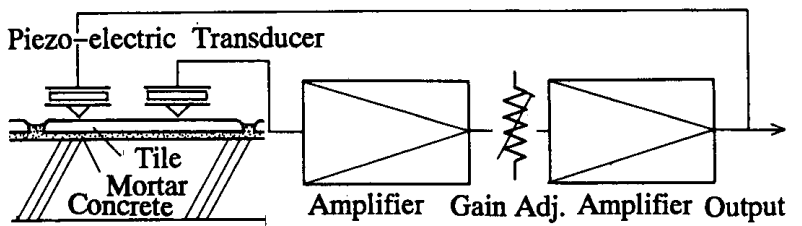

Fig. 12 An example of detecting circuit for tile in peeling off

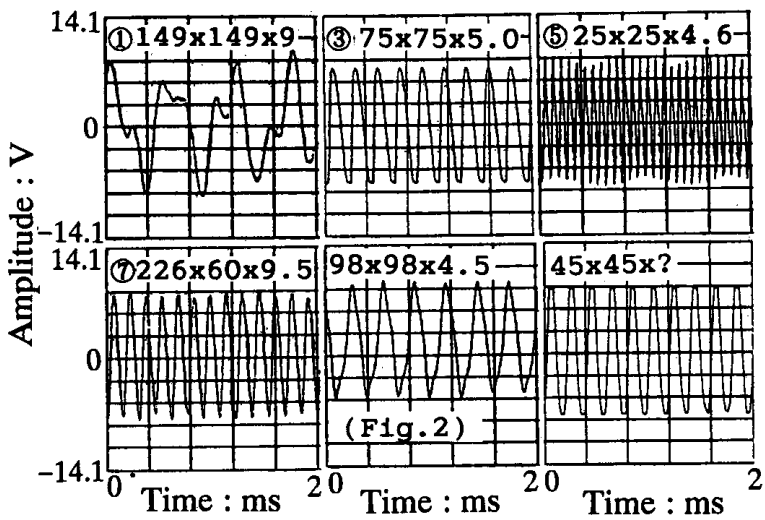

Fig. 13 Oscillating output signals obtained by peeling check tests using the detecting circuit

\section{2 検知装置の構成}

以上に述べた検討結果から，Fig. 12 に示すような具 体的な閉回路として, 裏面に接触用突起を付けた圧電ブ ザーと一般的な IC オペアンプで乾電池駆動可能な回路 を構成し, 模擬剝離タイルの試験体や実際に剥離してい るタイル壁を対象に以下の要領で検知試験を行った。

まず，正常なタイルに接触させた時の回路の発振開始 点を調べ, 実際の感度をそれよりいくぶん低く設定した。

その感度状態を保ちつつタイルに接触させると発振 し,圧電ブザーが発音して剝離タイルとして判定できた。

模擬剝離夕イルに接触させた時の代表的な発振波形を Fig. 13 に 4 例示すが，最も形状の大きな(1)が $2.4 \mathrm{kHz}$, 形状の小さな(5)で $13.5 \mathrm{kHz}$ と Fig. 4 や Fig. 5 に示され たピーク周波数にほぼ対応する波形が観測でき，前述の 検知方法の考え方の妥当性が確認された。

また，実際の剥離タイルに接触した時の出力波形を 2 例示すが，Fig. 2 に示した例の場合は $3.3 \mathrm{kHz}$ ，ある壁 面上の寸法 $4.5 \times 4.5 \mathrm{~mm}^{2}$ のタイルの場合は $5 \mathrm{kHz}$ の発 音が認められた。これ以外に，限られた数ではあるもの の，著者が打撃音で剥離状態と推定できたタイルにこの 装置を接触させるとほぼ発音することを確認している が，Fig.13に示した試験例からみても実用性が期待で きるものと考えられる。

\section{5.まとめ}

3., 4. の内容に関し以下のとおりまとめられる。 1）石こう接着によるタイルの振動特性はモルタル接着 によるタイルの振動特性に類似した結果が得られる。

2）剝離タイルを加振すると非剝離状態に比べ 20～30
$\mathrm{dB}$ 程度レベルの高いブロードなピーク周波数を持つ応 答を示す。その周波数は夕イル寸法によりほぼ決まる。 3）正常な接着状態では，タイルと質量の大きな背面の 母材とが振動的にほぼ一体となり励振されにくいが，剝 離状態になると，拘束は受けながらも夕イル単体の振動 に移行し，固有振動モードが現れやすく励振されやすい 状態（機械インピーダンスの低下）に変化する。

4）部分剝離タイルの場合, 剝離部分は永離タイルと,ま た非剝離部分は非剝離タイルと同等の振動特性を示す。

5）提示した触診型剝離検知法により, 実験のように夕 イル裏面の接着効果が無い，あるいはそれが部分的な剶 離状態か十分母材に接着した非剝離状態かの区分につい ては装置の発音之非発音で検知が可能である。

\section{6. あとがき}

模擬剝離夕イルの振動特性実験の結果に基づいて，構 成が簡単で安価な触診型の㓦離タイルの検知法を提示し た。これは, 単独使用の場合には手中に握れる大きさに 構成可能で, 打撃検查に代わる未熟練者向けの剝離検知 作業に利用できる。同時多チャンネル動作も可能で，い くぶんの複雑化をいとわなければ,タイル一枚の間隔で 並列に触診部を配置し, 平行移動させながら発振の有無 をマイコン処理する程度で外周壁の能率的な検査装置が 実現可能と思われる。

\section{謝 辞}

この研究を進めるに当たり，本学卒研生門間 司君 （現セキスイハウス）の多大なる協力を得た。また，試 験体を作製するに際し，本学の川瀬清孝教授に貴重なア ドバイスをいただいた。ここに記して深謝の意を表する。

\section{参考文献}

1）田中弘：建築技術選書 タイルの話, 学芸出版社, 1980

2）例えば, 是永雄二, 麦倉喬次, 足立 康：音声認識手法 を用いた衝撃性信号の認別手法, 日本音響学会講演論文 集, pp. 535 536, 昭和 59 年 3 月

3）岩瀬昭雄, 門馬 司：圧電ブザーを用いた虽離夕イルの 検出方法について, 日本音響学会講演論文集, pp. 639 640, 昭和 63 年 10 月

4）岩瀬昭雄：振動的手法による剝離タイルの検出方法につ いて, 日本建築学会大会学術講演梗概集, pp. 441 442, 1989 年 10 月

5）S.P. Timoshenko ほか, 谷口 修, 田村章義 共訳： 新版工業振動学, コロナ社, 1977

6）音響材料協会編：騒音・振動対策ハンドブック，技報堂 出版, 1982

7）前川純一：建築音響，共立出版，昭和 53 年（増訂）

(1992 年 6 月 5 日原稿受理, 1993 年 10 月 28 日採用決定) 